\title{
Miranda
}

Revue pluridisciplinaire du monde anglophone /

Multidisciplinary peer-reviewed journal on the English-

speaking world

13 | 2016

Thomas Spence and his Legacy: Bicentennial

Perspectives

\section{Linda by Penelope Skinner and The Wasp by Morgan Lloyd Malcolm}

Performance reviews

\section{William C. Boles}

\section{(2) OpenEdition}

\section{Journals}

Electronic version

URL: http://journals.openedition.org/miranda/9420

DOI: $10.4000 /$ miranda.9420

ISSN: 2108-6559

\section{Publisher}

Université Toulouse - Jean Jaurès

\section{Electronic reference}

William C. Boles, "Linda by Penelope Skinner and The Wasp by Morgan Lloyd Malcolm ", Miranda [Online], 13 | 2016, Online since 23 November 2016, connection on 16 February 2021. URL: http:// journals.openedition.org/miranda/9420 ; DOI: https://doi.org/10.4000/miranda.9420

This text was automatically generated on 16 February 2021.

\section{cc) (†)}

Miranda is licensed under a Creative Commons Attribution-NonCommercial-NoDerivatives 4.0

International License. 


\section{Linda by Penelope Skinner and The Wasp by Morgan Lloyd Malcolm}

Performance reviews

William C. Boles

\section{Factual information about the shows}

Play : Linda by Penelope Skinner

Place : Royal Court Theatre Downstairs (London)

Running time : November, 29 ${ }^{\text {th }}$, 2015-January, $9^{\text {th }}, 2016$

Director : Michael Longhurst

Set Designer : Es Devlin

Costume Designer : Alex Lowde

Lighting Designer : Lee Curran

Composer and Sound Designer : Richard Hammarton

Video Designer : Luke Halls

Movement Director : Imogen Knight

Cast: Imogen Byron, Karla Crome, Jaz Deol, NomaDumezweni, Amy Beth Hayes, Dominic Mafham, Merriel Plummer, Ian Redford 
Figure 1

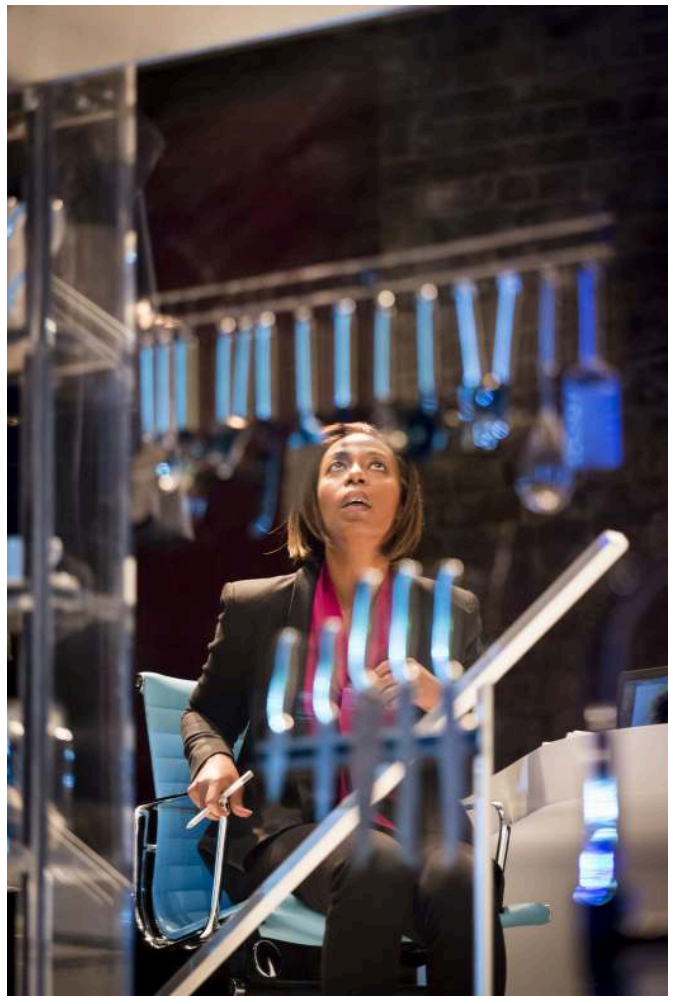

NOMA DUMEZWENI (LINDA)

JOHAN PERSSON 
Figure 2

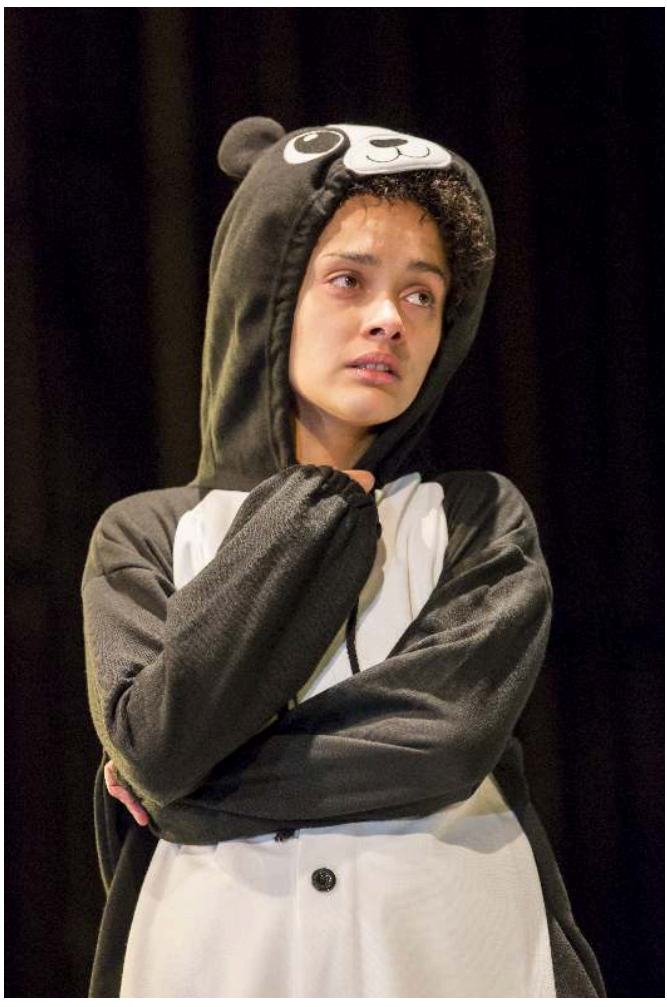

KARLA CROME (ALICE)

JOHAN PERSSON 
Figure 3

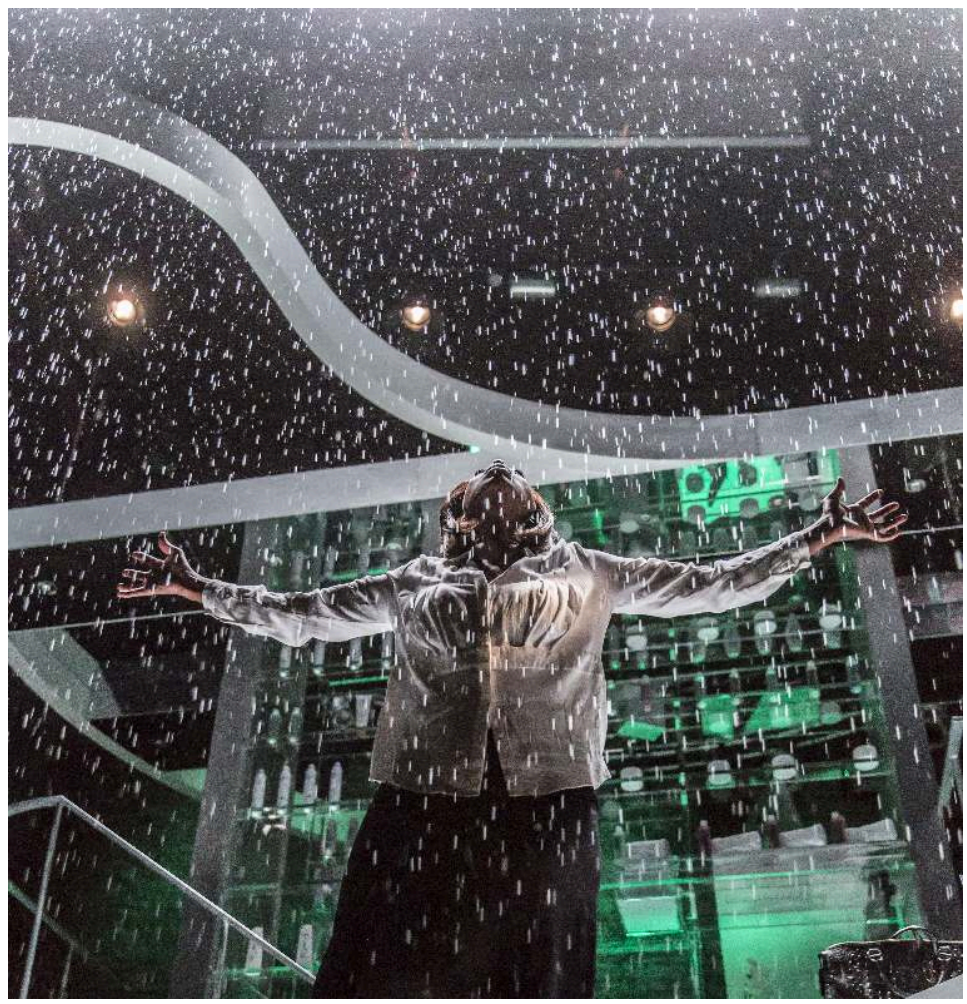

NOMA DUMEZWENI (LINDA)

JOHAN PERSSON

Play : The Wasp by Morgan Lloyd Malcolm

Place : Trafalgar Studios 2 (London)

Running time : December, 2015-January, $9^{\text {th }}, 2016$

Director : Tom Attenborough

Designer : David Woodhead

Lighting Designer : Oliver Fenwick

Sound Designer : Luke Swaffield

Composer : Edmund Rex

Cast : Laura Donnelly, MyAnnaBuring

\section{Review}

During the Christmas holidays the London theatre always features two staples : popular musicals playing to packed houses of Londoners catching a show during their week off from work and myriad pantos popping up in fringe theatres around town, filled with gleeful children yelling, "Look out behind you" to fairy tale ingénues. However, the holiday season of 2015 featured alternative programming of a more serious nature that explored the corrosive and devastating effects of bullying. Two productions produced South of the Thames looked at the immediate impact of bullying. Mike Bartlett's Bull (2013), revived at the Young Vic, details in less than an hour of running time the complete physical and psychological decimation of a business man by two of his coworkers who harass him over his clothing, work ethic, physical appearance, status at work, and, finally, his failed family life. Up the road at the National Theatre in the 
Olivier Theatre, Moira Buffini's wonder.land, a contemporary musical reworking of Lewis Carroll's Alice in Wonderland, opens with a scene of three girls cyber bullying Aly about her weight, appearance and family, driving her to escape into the virtual game world of wonder.land, where she can create a completely different person via an avatar. Both of these productions offered narratives where the victim's reaction to the bullying is the driving force of the story and is a dramatic situation oft seen in the media. However, much like Joel Edgerton's film The Gift (2015), Penelope Skinner's Linda (2015) and Morgan Lloyd Malcom's The Wasp (2015) examine the long term effects of bullying on the victim, who has struggled to move beyond her devastating high school experience with her oppressor.

Bullying exists on multiple levels in Penelope Skinner's Linda, which details the business and personal travails of title character Linda (powerfully played by Noma Dumezweni, who was a last minute replacement for an ill Kim Cattrall), a successful, middle-aged, marketing strategist for a beauty product company, who discovers that her latest product campaign to focus on women over 50 does not align with the philosophical or economic plans of her company. Her argument that woman of a certain age becomes invisible (unless they are Helen Mirren) fails to convince her older male boss, who wants the demographic for their next product to skew younger. In order to enact this business plan he promotes Amy (Amy Beth Hayes), a 25-year-old, blonde, attractive, up and coming marketing employee to oversee the roll out, while Linda is assigned to report to her younger co-worker. Linda quickly discovers that not only is she starting to become invisible at work but also at home to her husband, who is having an affair with the younger lead singer of his band, and two daughters. In essence, Linda is experiencing a full blown identity crisis, instigated by a bullying societal perspective that women of a certain age no longer have value and should accept their fate, moving to the side and out of the way for women like Amy. Linda, though, refuses to be controlled by the societal prejudice and displacement of her power, and in the first act's final scene, which shows off skinner's biting and empowering writing at its best, Linda rebels against her entire company ethos. Refusing to be pushed to the side for a younger employee, she excoriates her coworkers, board members, and others in terms of how women are treated, refusing to be invisible. It is an incredible theatrical performance by Dumezweni and wonderfully crafted by Skinner, but unfortunately, it is also the high point of the play. In the second act her rebellion goes for naught, as she loses employment at her company because she embarks on a disastrous (and not entirely believable) interoffice affair with one of her underlings.

$5 \quad$ While Linda struggles mightily against society's dismissal of older women, her eldest daughter Alice (Karla Crome) has been suffering throughout the past ten years of her life because of a bullying incident that occurred when she was fifteen. At that time she was in a relationship with a boy at school and, on a whim, sent him some nude photos. Once they broke up, he shared them with friends, who then released them to the entire student body. Horrified and embarrassed, she transferred to another school, only to find the photos following her there and to subsequent places she went. The experience drove her into a constant state of self-harming (at one point she changes clothing and we see that she has cut marks all over her body) and self-separation from society by locking herself up at home. In order to avoid observation by others, she wears the same animal onesie every day, arguing that in regular clothes people would notice her, but in 
her onesie, she becomes invisible, no one casts a second glance at her in a sexual manner when she wears such an outfit. For ten years the power of cyber bullying has decimated her fragile ego and sense of self. In contrast to her mother, she longs to be invisible and seeks it out. She relishes the anonymity connected with her current identity. Adding to her difficulties has been Linda's lack of emotional support to her daughter over the decade, as she has offered weak maxims of encouragement as the rising arc of her career has superseded the downdraft of her daughter's mental and physical state.

6 However, what Skinner provides is an interesting overlap between daughter and mother in that one of the bullies who destroyed Alice is the same woman who destroys Linda : Amy. A classmate of Alice's, Amy helped spread the photos around campus and to subsequent locations. As a colleague of Linda's, Amy gets a hold of emails shared between Linda and Luke, the younger co-worker Linda has the tryst with, and, as she did with Alice, she spreads them around the office, destroying Linda's reputation and, in turn, positioning herself to move up in the company. In finally experiencing the devastation that her daughter experienced ten years earlier, Linda's rage overtakes her, choking Amy in revenge for what has been done to her and Alice. However, Linda stops short of killing her and escapes up to the roof of her company's building, while a hurricane (believably done on stage as rain and wind pour over the characters and rotating set) lashes the city. The play goes to black as Linda walks out into the storm, leaving the audience to decide if Linda commits suicide, but no matter the choice, the damage has been done to her career, family and self-esteem.

7 Skinner ends the play with a flashback from ten years earlier, just before the photos of Alice were sent out, as Linda accepts an award for a successful beauty campaign. She ends her speech by espousing how great the future is going to be for women. However, like Caryl Churchill's Top Girls (1982), the play offers the same ironic statement about the future role of women in society and their limited potential for advancement. Clearly, Skinner indicates that there is still a long way to go for women, especially when the greatest impediment for a woman's success continues to be another woman.

8 As in Linda, female relationships are the focus of Morgan Lloyd Malcolm's The Wasp, as two former high school friends meet up at a café twenty years after their friendship disintegrated. However, unlike in Linda where neither Linda nor Alice are able to overcome Amy's actions against them, Malcolm presents a scenario where the victim finally extracts not only physical revenge upon her oppressor but also emotional closure for herself.

9 Heather (a sneakily good Laura Donnelly in her subtle transformation from victim to hunger) is the more successful of the two former classmates, indicated by her clothing, bearing and proper English accent, while Carla (played by MyAnna Buring, who captures her character's rough edges, while also allowing her vulnerable aspects to peak through the tough exterior), in her final trimester and chain smoking, has never escaped from her lower class status, trapped there by her good-for-nothing older husband and four kids. Heather has initiated the meeting with Carla to ask her for help. She has caught her husband Simon being unfaithful to her and she wants revenge for his callous treatment of her. Even though they haven't spoken for twenty years, she has called Carla because she remembers her inherent brutality from their days at school, demonstrated on a walk home from school when she viciously stomped a pigeon to death, smearing its entrails all over the ground. Knowing from online postings that 
Carla is financially disadvantaged and wants to leave her husband, Heather offers Carla twenty thousand pounds to kill Simon.

However, when they meet again to finalize the details at Heather's home, more of their past relationship is revealed, namely that after their friendship fell apart, due to Carla's anger over Heather's seemingly perfect happy home versus her economically disadvantaged situation and physically abusive father, Carla and her gang began to bully Heather. First, Carla spread lies about Heather masturbating in a shower (leading to Heather getting a reputation for sexual proclivities), then Carla jumped her, giving Heather a black eye that lasted for two weeks. Finally, a year after the attack, Carla and her gang sexually assaulted Heather, inserting an object into her vagina in a darkened girl's bathroom during a school dance.

11 Carla tries to dismiss these actions as something that just happens because it was high school, that all teens act that way, but soon finds herself growing more and more unsteady on her feet. Heather reveals that she actually does not want Carla to kill her husband-it was merely a ruse to get her into her home where she could drug her and tie her to a chair. Whereas Linda and Alice are never able to punish Amy for her transgressions, Heather's plan is all about revenge. Since she was assaulted at the dance, she has never felt completely whole. There has been something stuck inside her, preventing her from feeling complete. Malcolm makes a metaphorical comparison (a bit heavy handed) between Heather's physical/emotional condition and a Tarantula Hawkwasp that is pinned in a frame on the wall of her home. In order to maintain the species the wasp stings a tarantula and inserts an egg into the body cavity of the insect, where the egg gestates, feeding off the tarantula for its nutrients. When it becomes full size, it burst out of the body, killing its host. Carla is the wasp, who twenty years earlier, inserted the pain into Heather and it has continued to gestate. Heather finally realizes that the only one who can remove the pain is the person who placed it there. Heather releases Carla from her bonds and places her knife to the side, indicating that she has no intentions of causing any further harm to her. However, Carla, still uncertain of Heather's motifs and further surprises she might have in store for her, grabs the knife and stabs her, releasing her from her suffering. Just as Heather collapses to the floor, her husband oliver enters and a blackout occurs. Heather finally has the pain of twenty years removed and Carla finally will receive her comeuppance for the damage she has done to her former friend.

Both plays provide a powerful commentary on the long lasting effects of bullying and its power to ruin someone's life in the decades to follow. Linda sets out to cover a variety of topics as they relate to the role of women over the last decade, bullying being one of many, and in her main character's mind the action of bullying is minor when compared with the greater strides to be made by women's in the business world. However, Skinner shows that such attitudes have consequences, as the same person who bullied her daughter ends up destroying Linda's career. Ultimately, the play articulates that as much as Linda craves success in her professional space, she does an injustice to the next generation by ignoring her own daughters. In contrast Malcolm takes a far more proactive (albeit late) response to the actions of bullying by having the victim finally serve justice to the woman who terrorized her. True, Helen's victory is fatally sweet, but the twenty year path is filled with silent suffering. In both plays the playwrights demonstrate not only how much influence and resonance the words and 
actions of high schoolers have into adult life but also the powerful disruption caused by women who turn on one another instead of supporting one another.

\section{ABSTRACTS}

Theatre reviews, January 2016

Shows: Linda by Penelope Skinner-Royal Court Theatre (London), November, $29^{\text {th }}, 2015$ January, $9^{\text {th }}, 2016$; The Wasp by Morgan Lloyd Malcolm-Trafalgar Studios (London), December, 2015-January, $9^{\text {th }}, 2016$.

Critique théâtrale, January 2016

Spectacles: Linda de Penelope Skinner-Royal Court Theatre (Londres), 29 novembre 2015-9 janvier, 2016 ; The Wasp de Morgan Lloyd Malcolm-Trafalgar Studios (Londres), décembre 2015-9 janvier 2016.

\section{INDEX}

Subjects: Theater

Keywords: plays, Christmas season, bullying, friendship, identity crisis, societal prejudices, invisibility, revenge

Mots-clés: pièces, programmation de Noël, harcèlement, amitié, crise identitaire, préjudices sociaux, invisibilité, revanche

\section{AUTHOR}

\section{WILLIAM C. BOLES}

Professor

Rollins College, Florida (USA) 